\title{
Determinant of Capital structure of Nepalese hydropower companies
}

\author{
Prem Lal Rajbanshi \\ Lecturer, Nepal Commerce Campus, T.U.
}

\begin{abstract}
This study examines the effect of profitability, liquidity, size, tangibility and tax shield on capital structure of Nepalese Hydropower Companies. Debt ratio and long term debt to total assets ratio are taken as dependent variable and Profitability, liquidity, size, tangibility and tax shield are as independent variable. The study reveals that tangibility and non debt tax shield are positively influence the total debt where as profitability and liquidity are negatively influence on the total debt decision of the Nepalese Hydropower Companies. The regression coefficients for size are neither consistent nor statistically insignificant in all regression equations indicating that size variable is not the major factor of determinant of total debt as well as long term debt.
\end{abstract}

\section{Introduction}

The choice of debt-equity still remains an unresolved issue. A pioneer work of MM (1958) and other many studies have been conducted to find a logical explanation in which capital structure matters. MM argued that the value of the firm is independent of its capital structure (Modigliani \& Miller, 1958). Several studies have been conducted in developed countries in capital structure and equity timing; however limited studies have been carried out in the context of Nepal. Raising cash in capital markets is accomplished usually at discrete intervals, thus at some point in time the firm will evaluate the state of these markets and consider the possible effects of a current decision on future financing flexibility (Van Horne, 1974). Graham \& Harvey (2001) argued that firms which require new finance tend to issue equity if they are above their target debt level and issue debt if they are below.

Generally size, collateral value of assets, growth opportunities, marginal tax rate, research and development to sales are the basic determinants of capital structure as a manner consistent with prediction of trade off theories. The trade off theories also supported by studies that report that deviation from target leverage is a key determinant of issuing debt-equity choice. On the other hand, Shyam and Myers (1999) contended that firm follows pecking order hypothesis outperforms the target adjustment in explaining the time series variation in debt ratios.

Baker and Wurgler (2002) reported that historical market to book ratios, averaged using a weighting scheme where market to book ratios in years with higher external financing receive higher weights, have a statistically and economically significant impact on current capital structure. The authors documented that neither the trade-off nor the pecking order model is consistent with the negative effect of long past market to book ratio on firms financial leverage. Instead, they opined that firms time their net equity issues to equity market conditions, and that the changes in capital structure induced by these issues persists as firms do not care to adjust their leverage position toward the target in succeeding years results observed capital structures reflect the cumulative outcome of timing the equity market.

The efficiency of the firm can be evaluated with the help of financial statement which throws some 
light on operational performance of the firm. The optimal financial structure is determined by trading off amid the benefits of managerial access to bad ones (Harris \& Raviv, 1992). Myers (2001) contended that study of capital structure attempts to explain the mix of securities and financing sources used by firms to finance real investment.There is a negative effect on current leverage, change in leverage and debt versus equity issuance can be obtained using a weighted average market to book ratio based on future rather than past market to book ratios and external financing (Hovakimian, 2006).

\section{Literature Review}

A review of previous study is important as it provides the basic foundation to the study of impacts of market timing on capital structure in the Nepalese context. After getting the knowledge of different methodology used in the previous study, the researcher allows to understand the context and limitation of the study.

\section{Review of recent studies}

Doukas, Guo and Zhou (2010) found that firms issue more debt during hot periods to repurchase shares, suggesting that managers also actively substitute debt and equity. Contrary to predictions of the theory, firms with larger bankruptcy costs, i.e. smaller firms and firms with lower asset tangibility, choose capital structures with higher bankruptcy risk. Further analysis asserts that the capital structure of smaller firms with lower asset tangibility, which tend to have less access to capital markets, are more sensitive to negative profitability and equity value shocks, making them more susceptible to bankruptcy risk (Hovakimian et al., 2011). Guney and Hussain (2012) found that both security issue and repurchasing choice and size is driven by equity mispricing, indicating that market timing plays important role in both decisions. Li and Tam (2012) indicated that transaction costs both capital market timing and capital structure rebalancing. Past market timing activity has a significantly negative impact on the current debt ratio, and this impact is stronger for firms facing lower transaction costs of external financing. Panigrahi (2012) concluded that when firms need external financing tend to issue debt. The study further concluded that larger the size of the firm the higher the level of debt and vice versa. Mokhova and Zinecker (2013) studied the impact of size, growth, profitability, tangibility, and non-debt tax shields on the leverage and found that profitability and size have negative and significant impact on the leverage of most of the countries. The study also found that tangibility, growth opportunities and non-debt tax shields have positive impact in some countries and negative on the others. Ghazouani (2013) argued thatprofitability, assets tangibility, risk, size, and growth rate were the variables used in the study. Two major determinants of capital structure in Tunisian firms were found to be profitability and asset structure according to the results of the study. Fauzi et al. (2013) identified that non-debt tax shields, profitability, size, tangibility, growth, signaling, and managerial ownership were the determinants of capital structure.

\section{Review of Nepalese studies}

Very few studies have been conducted in Nepalese context. Most of the early studies were clustered around capital structure pattern of public enterprises.

Shrestha (1993) concluded that profitability was negative and interest payment on debt was serious issue. She, further, concluded that most of the PEs has no transparent capital structure and companies determined their capital structure without realistic parameters. K.C. (1994) found significant positive relationship of long-term debt with growth, assets structure and age of incorporation. Poudel (1994) concluded that size, profitability, growth, assets structure and cash flow variability have the influence on the capital structure. He observed that size and growth were positively related to leverage and risk, profitability and assets structure were negatively related to leverage for both listed companies and PEs. Baral (2004) showed that size, growth rate and earning rate are statistically significant determinants of 
capital structure of the listed companies. Sherpa (2007) found different impact of firms specific variable according to the leverage measures. Liquidity and asset tangibility had negative impact on total debt ratio, while size, profitability, risk, asset tangibility and non-debt tax shield had positive impact on longterm debt ratio. Bhattarai (2008) revealed that firm size, profitability, liquidity and asst tangibility are the most influencing factors in determining the capital structure in manufacturing firms; whereas firm's size, liquidity, profitability and age are influencing factors in capital structure decisions in non- manufacturing firms. Adhikari (2010) concluded that Nepalese firms are highly levered and rely more on short term debt and the average profitability is negative that shows the weak performance. Profitability, earnings variability and growth have negative influence on leverage ratio but size has positive impact on debt ratio.

\section{Theoretical framework}

Large numbers of studies have found the effect of firm's specific variables on capital structure. In this empirical study, leverage (capital structure) has been used as dependent variable and Size, Tangibility, profitability, non-debt tax shield, and liquidity have been used as independent variables. Based on the review of capital structure theories and major empirical studies following theoretical framework has been developed as depicted in figure 2.1

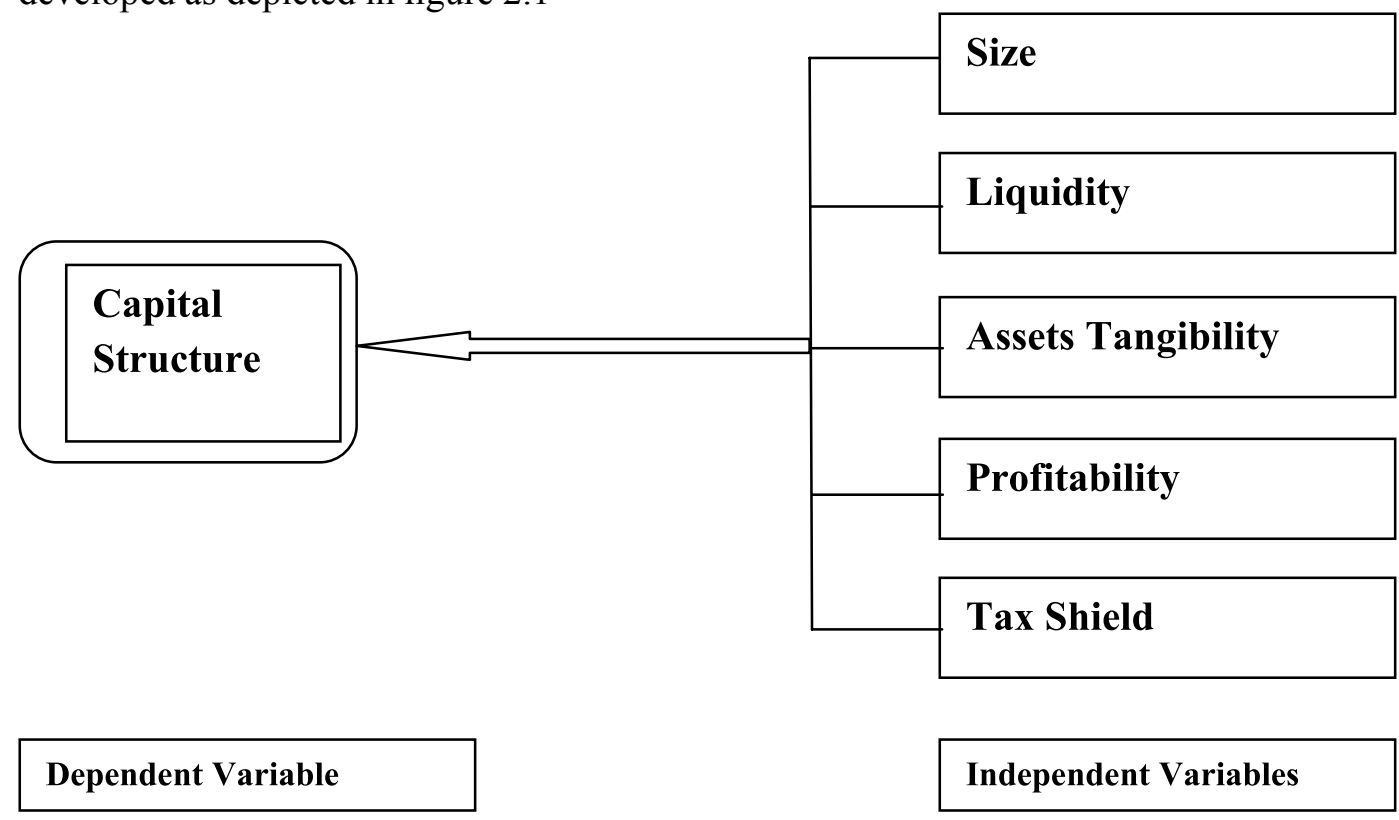

Figure 1 Theoretical framework

\section{Research Methodology}

The research methodology is a collective terminology for the detailed and organized manner and procedure of conducting a research. It includes a various techniques of data gathering, analysis and research design.

A descriptive and casual comparative research design has been adopted for the study as it seeks to identify the key determinant of capital structure of Nepalese hydropower companies All the Nepalese Hydropower Companies listed in the Nepal Stock Exchange (NEPSE) have been taken as the population of the study. The sample selected for the study has fourteen hydropower companies due to availability of sales. Sales is used as proxy of size. This study is based on the analysis of secondary data. The necessary data required for this study has been collected from NEPSE and annual reports of concerned companies

The study has been carried out on secondary data analysis. The collected data were recorded in excel sheet then analyze with the help of SPSS 20 version. The method of analysis employed in this study includes descriptive analysis and inferential analysis has been applied. 
The study has used capital structure as dependent variable. In relation to independent variable, the study has selected tangibility, size, profitability, liquidity and non debt tax shield ratio as independent variable. The definition of these variables has been presented here under.

\section{Empirical model}

Statistical tools along with econometric models have been used to analyze the predictive power of explanatory variables such as firm size, tangibility, profitability, non-debt tax shield, and liquidity. Ordinary least square regression model has been conducted for pooled data to identify the impact and predictive power of explanatory variables. The regression analysis determines the predictive power of each of the explanatory variables in explaining leverage of the firms. The study has performed simple linear regression and multiple regression models to establish the relationship between debt ratio and each of the explanatory variables. The models used for regression analysis is presented as follows.

$\mathrm{TDR}=\alpha+\beta_{1}\left(\mathrm{SIZE}_{\mathrm{it}}\right)+\beta_{2}\left(\mathrm{TANG}_{\mathrm{it}}\right)+\beta_{3}\left(\mathrm{PROF}_{\mathrm{it}}\right)+\beta_{4}\left(\mathrm{LIQ}_{\mathrm{it}}\right)+\beta_{5}\left(\mathrm{NDTS}_{\mathrm{it}}\right)+\varepsilon$

$\mathrm{LTDR}=\alpha+\beta_{1}\left(\mathrm{SIZE}_{\mathrm{it}}\right)+\beta_{2}\left(\mathrm{TANG}_{\mathrm{it}}\right)+\beta_{3}\left(\mathrm{PROF}_{\mathrm{it}}\right)+\beta_{4}\left(\mathrm{LIQ}_{\mathrm{it}}\right)+\beta_{5}\left(\mathrm{NDTS}_{\mathrm{it}}\right)+\varepsilon_{\mathrm{i}}$

\section{Results}

The firms may follow different approaches while managing capital structure. The capital structure theories provide basic guidelines in this respect however, a particular theory will not sufficient to deal with these issues. It employs the various econometric and statistical tools and techniques in order to determine capital structure and its determinants.

Table 1

Total debt ratio of all the sample Companies

The table displays the summary statistics of total debt ratio of different companies used in this study that reports the mean, standard deviation, minimum and maximum values including number of cases of listed Hydropower Companies. The total debt ratio is is defined as total debt divided by total assets.

\begin{tabular}{ccccccc}
\hline S.N & Com. & N & Minimum & Maximum & Mean & Std. dev. \\
\hline 1 & API & 2 & 0.4322 & 0.5342 & 0.4832 & 0.0721 \\
2 & AV & 9 & 0.0251 & 0.3981 & 0.19 & 0.1525 \\
3 & BR & 3 & 0.5946 & 0.7059 & 0.6688 & 0.0642 \\
4 & BPC & 13 & 0.0404 & 0.5403 & 0.2951 & 0.1398 \\
5 & CH & 13 & 0.0177 & 0.4819 & 0.1488 & 0.142 \\
6 & NHD & 4 & 0.6762 & 0.7988 & 0.7446 & 0.0155 \\
7 & NHPC & 6 & 0.1184 & 0.3326 & 0.2265 & 0.0897 \\
8 & RA & 3 & 0.2965 & 0.5949 & 0.4288 & 0.1458 \\
9 & RR & 4 & 0.7195 & 0.7471 & 0.7291 & 0.0155 \\
10 & RI & 5 & 0.1855 & 0.6732 & 0.3549 & 0.1889 \\
11 & SM & 5 & 0.5693 & 0.7679 & 0.6829 & 0.0748 \\
12 & SY & 5 & 0.6299 & 0.8237 & 0.7591 & 0.0748 \\
13 & UM & 4 & 0.4619 & 0.7425 & 0.6142 & 0.1955 \\
\hline
\end{tabular}

Table 1 describes the total debt ratio company wise. The highest variability in total debt ratio is observed for Ridi Hydro Power Limited (18.89\%) and least variability is observed for Nepal Hydro Development Company Limited (1.55\%) among all the companies under study. The highest total debt ratio is observed in the year 2016 for the Synergy Power Company is (82.37\%) and the lowest is for the Arun Valley Hydropower Company is (2.51\%) in the year 2017. 
Table 2

Long term debt ratio of all the sample companies

The table displays the summary statistics of long term debt ratio of different companies used in this study that reports the mean, standard deviation, minimum and maximum values including number of cases of listed Hydropower Companies. and long term debt by total assets. The long term debt ratio is defined as long term debt divided by total assets.

\begin{tabular}{ccccccc}
\hline S.N. & Com. & N & Minimum & Maximum & Mean & Std. dev. \\
\hline 1 & API & 2 & .3999 & .4689 & .4344 & .0488 \\
2 & AV & 9 & .00 & .2581 & .035 & .073 \\
3 & BR & 3 & .4736 & .6156 & .5491 & .0734 \\
4 & BPC & 13 & .00 & .3769 & .1025 & .1025 \\
5 & CH & 13 & .00 & .3282 & .0565 & .1036 \\
6 & NHD & 4 & .5353 & .7159 & .6154 & .0769 \\
7 & NHPC & 6 & .0994 & .3106 & .2089 & .0798 \\
8 & RA & 3 & .5575 & .7071 & .6319 & .0748 \\
9 & RR & 4 & .1476 & .5479 & .3227 & .1713 \\
10 & RI & 5 & .0932 & .4722 & .2335 & .1469 \\
11 & SM & 5 & .5165 & .7145 & .6189 & .0752 \\
12 & SY & 5 & .5945 & .7284 & .6744 & .0507 \\
13 & UM & 4 & .4496 & .7352 & .5997 & .1222 \\
\hline
\end{tabular}

Table 2 describes the long term debt ratio company wise. The highest variability in long term debt ratio is observed for Rairang Hydro Power Limited (17.13\%) and least variability is observed for Api Hydro Development Company Limited (5.07\%) among all the companies under study. The highest total debt ratio is observed in the year 2013 for the United Modi Hydropower Company is (73.52\%) and the lowest is for the Arun Valley, Chilime and Butwal Power Company are (0\%). Table 4.3, provides descriptive statistics for leverage, size, tangibility, profitability, liquidity and non debt tax shield variables. Total debt ratio ranges from minimum 0.0177 to maximum 0.8237 , with a mean value of 0.399 , and a standard deviation of 0.25 . This wider fluctuation indicates that the sample includes both high and low value firms. Long term debt ratio ranges from minimum 0.00 to maximum 0.7352 , with a mean value of 0.29 , and a standard deviation of 0.26 . Size (ln sales) ranges from minimum 0.76 to maximum 7.09 , with a mean value of 0.4 .93 , and a standard deviation of 1.55 .. Tangibility ranges from minimum 0.1131 to maximum 0.9747 , with a mean value of 0.7569 , and a standard deviation of 0.3397 . Profitability ranges from minimum -0.0246 to maximum 0.2999 , with a mean value of 0.092 , and a standard deviation of 0.0683 . Liquidity ranges from minimum 0.1013 to maximum 33.63, with a mean value of 3.44 , and a standard deviation of 6.12 . Non debt tax shield ranges

Table 3

Descriptive statistics of the variables under study for all sample firms

The table displays the mean, standard deviation, minimum, maximum and $\mathrm{cv}$ values of dependent and independent variables of listed Hydropower Companies. The leverage is defined as total liabilities divided by total assets and long term debt by total assets. Size is the log of sales, tangibility is the property, plant and equipment divided by total assets, profitability is defined as operating income before depreciation divided by total assets. Liquidity is defined by current assets divided by current liabilities. Non debt tax shield is the ratio of depreciation and fixed assets from minimum 0.0007 to maximum 0.1044 , with a mean value of 0.025 , and a standard deviation of 0.0163 . 
Silver Jubilee Issue - 2019

\begin{tabular}{ccccccc}
\hline Variables & $\mathrm{N}$ & Minimum & Maximum & Mean & Std. deviation & $\mathrm{CV}$ \\
\hline TDR & 77 & .0177 & .8237 & .399149 & .2534409 & .635 \\
LTDR & 77 & .0000 & .7352 & .290453 & .2609043 & .898 \\
Ln_Size_M & 77 & .76 & 7.09 & 4.9298 & 1.55943 & .316 \\
TANG & 77 & .1131 & .9747 & .756949 & .2297701 & .303 \\
Profitability & 77 & -.0246 & .2999 & .092005 & .0683777 & .743 \\
Liquidity & 77 & .1013 & 33.6367 & 3.444812 & 6.1244897 & 1.778 \\
NDTS & 77 & .0007 & .1044 & .025253 & .0163898 & .649 \\
\hline
\end{tabular}

\section{Table 4}

Pearson correlation analysis among the variables under study of all sample firms

The table depicts the correlation analysis of the major variables under study. The correlation analysis is conducted for the whole sample. The sample includes 77 observations for different periods. The leverage is defined as total liabilities divided by total assets and long term debt by total assets. Size is the log of sales, tangibility is the property, plant and equipment divided by total assets, profitability is defined as operating income before depreciation divided by total assets. Liquidity is defined by current assets divided by current liabilities. Non debt tax shield is the ratio of depreciation and fixed assets.

\begin{tabular}{llllllll}
\hline Variables & TDR & LDR & SIZE & TANG & PROF & LIQ & NDTS \\
\hline TDR & 1 & & & & & & \\
LDR & $.917^{* *}$ & 1 & & & & & \\
SIZE & $-.380^{* *}$ & $-.379^{* *}$ & 1 & & & & \\
TANG & $.442^{* *}$ & $.488^{* *}$ & $-.451^{* *}$ & 1 & & & \\
PROF & $-.563^{* *}$ & $-.67^{* *}$ & $.667^{* *}$ & -.302 & 1 & & \\
LIQ & $-.456^{* *}$ & $-.319^{* *}$ & $.319^{* *}$ & $-.543^{* *}$ & $.302^{* *}$ & 1 & \\
NDTS & .103 & -.007 & .193 & $.254^{*}$ & $.355^{* *}$ & -.157 & 1 \\
\hline
\end{tabular}

**.Correlation coefficient is significant at the 0.01 level (2-tailled).

*. Correlation coefficient is significant at the 0.05 level (2-tailled).

The table 4 reports Pearson correlation matrix among the measures of capital structure and all independent variables for all sample firms for the different periods. All the correlations can be considered as low since the highest correlation has been observed to be 0.917 between Total debt ratio and Long term debt ratio which are dependent variables. The lowest correlation of -.007 has been observed between Long term debt ratio and Non debt tax shield and is not significant. The result shows that there is a low degree of correlation (correlation less than 0.8) between the variables indicating there is no problem of multicollinarity. It is also checked by VIF. For all variables VIF are less than 10, so there is no problem of multicollinarity. On drawing non plot of residuals, there is no any pattern. From this it is clear that the data is homoscedastic.

Table 5

Regression results of total debt for Nepalese hydropower companies

This table presents the results of regression model designed to analyze the impact of five firms' specific variables on total debt of hydropower companies. The sample includes 77 observations for different periods. The leverage is defined as total liabilities divided by total assets. Size is the log of sales, tangibility is the property, plant and equipment divided by total assets, profitability is defined as operating income before depreciation divided by total assets. Liquidity is defined by current assets divided by current liabilities. Non debt tax shield is the ratio of depreciation and fixed assets. The figures in the parentheses are t-values and (*) and (**) indicates that the result is significant at 1 and 5 percent level. The Table also presents the value 
of F-statistic and R-square value of each model used for the analysis purpose.

\begin{tabular}{|c|c|c|c|c|c|c|c|c|c|c|}
\hline Model & (Constant) & SIZE & TANG & PROF & LIQ & NDTS & $\mathrm{R}^{2}$ & $\begin{array}{c}\text { Adjusted } \\
\mathrm{R}^{2}\end{array}$ & $\mathrm{~F}$ & Sig \\
\hline 1 & $\begin{array}{c}.705 \\
\left(7.85^{*}\right)\end{array}$ & $\begin{array}{c}-.062 \\
\left(-3.56^{*}\right)\end{array}$ & & & & & .145 & .133 & 12.66 & .001 \\
\hline 2 & $\begin{array}{c}.03 \\
(.335)\end{array}$ & & $\begin{array}{c}.448 \\
\left(4.27^{*}\right)\end{array}$ & & & & .195 & .185 & 18.22 & .000 \\
\hline 3 & $\begin{array}{c}.519 \\
(14.62 *)\end{array}$ & & & $\begin{array}{c}-2.087 \\
(-5.89 *)\end{array}$ & & & .317 & .308 & 34.79 & .000 \\
\hline 4 & $\begin{array}{c}.464 \\
(15.62 *)\end{array}$ & & & & $\begin{array}{c}-.019 \\
\left(-4.44^{*}\right)\end{array}$ & & .208 & .198 & 19.71 & .000 \\
\hline 5 & $\begin{array}{c}.359 \\
\left(6.73^{*}\right)\end{array}$ & & & & & $\begin{array}{l}1.599 \\
(.90)\end{array}$ & .011 & .002 & .81 & .37 \\
\hline 6 & $\begin{array}{c}.297 \\
(1.85)\end{array}$ & $\begin{array}{c}-.037 \\
(-1.99 * *)\end{array}$ & $\begin{array}{c}, 375 \\
\left(2.98^{*}\right)\end{array}$ & & & & .236 & .216 & 11.46 & .000 \\
\hline 7 & $\begin{array}{r}.613 \\
\left(16,27^{*}\right)\end{array}$ & & & $\begin{array}{c}-1.79 \\
\left(-5.35^{*}\right)\end{array}$ & $\begin{array}{c}-.014 \\
\left(-3,81^{*}\right)\end{array}$ & & .429 & .413 & 27.77 & .000 \\
\hline 8 & $\begin{array}{c}.19 \\
(1.32 *)\end{array}$ & $\begin{array}{c}.023 \\
\left(1.12^{*}\right)\end{array}$ & $\begin{array}{c}.347 \\
\left(3.36^{*}\right)\end{array}$ & $\begin{array}{c}-2.06 \\
\left(-4.61^{*}\right)\end{array}$ & & & .409 & .384 & 16.81 & .000 \\
\hline 9 & $\begin{array}{c}.536 \\
(12.01 *)\end{array}$ & & & $\begin{array}{c}-2.21 \\
(-6.32 *)\end{array}$ & $\begin{array}{c}-.011 \\
\left(-3.08^{*}\right)\end{array}$ & $\begin{array}{c}4.203 \\
\left(2.93^{*}\right)\end{array}$ & .489 & .468 & 23.27 & .000 \\
\hline 10 & $\begin{array}{c}.361 \\
(2.51 *)\end{array}$ & $\begin{array}{c}.022 \\
(1.12)\end{array}$ & $\begin{array}{l}.122 \\
(.98)\end{array}$ & $\begin{array}{c}-2.39 \\
(-5.39 *)\end{array}$ & $\begin{array}{c}-.01 \\
(-2.49 *)\end{array}$ & $\begin{array}{c}3.70 \\
(2.42 *)\end{array}$ & .501 & .466 & 14.24 & .000 \\
\hline
\end{tabular}

Table 5 describes about regression of independent variables on total debt ratio. Profitability has been found to be an important factor affecting total debt as beta coefficients are consistently negative and statistically significant at 1 percent level of significance in all the equitation. It indicates that higher the profitability ratio, lower would be the total debt. Liquidity has been found to be an important factor affecting total debt as beta coefficients are consistently negative and statistically significant at 1 percent level of significance in all the equitation. It indicates that higher the liquidity ratio, lower would be the total debt.The regression coefficients for size are neither consistent nor statistically insignificant in all regression equations indicating that size variable is not the major factor of determinant of total debt.The evidence shows that tangibility and non debt tax shield are positively influence to the total debt where as profitability and liquidity are negatively influence on the total debt of the Nepalese Hydropower Companies.

Table 6

Regression results of long term debt for Nepalese hydropower companies

This table presents the results of regression model designed to analyze the impact of five firms' specific variables on long term debt of hydropower companies. The sample includes 77 observations for different periods. The leverage is defined as total liabilities divided by total assets. Size is the log of sales, tangibility is the property, plant and equipment divided by total assets, profitability is defined as operating income before depreciation divided by total assets. Liquidity is defined by current assets divided by current liabilities. Non debt tax shield is the ratio of depreciation and fixed assets. The figures in the parentheses are $t$-values and (*) and (**) indicates that the result is significant at 1 and 5 percent level. The Table also presents the value of F-statistic and R-square value of each model used for the analysis purpose. 


\begin{tabular}{|c|c|c|c|c|c|c|c|c|c|c|}
\hline Model & (Constant) & SIZE & TANG & PROF & LIQ & NDTS & $\mathrm{R}^{2}$ & $\begin{array}{c}\text { Adjusted } \\
\mathrm{R}^{2}\end{array}$ & $\mathrm{~F}$ & Sig \\
\hline 1 & $\begin{array}{c}.603 \\
\left(6.53^{*}\right)\end{array}$ & $\begin{array}{c}-.063 \\
\left(-3.55^{*}\right)\end{array}$ & & & & & .144 & .132 & 12.57 & .001 \\
\hline 2 & $\begin{array}{c}-.129 \\
(-1.43)\end{array}$ & & $\begin{array}{c}.555 \\
\left(4.85^{*}\right)\end{array}$ & & & & .239 & .228 & 23.49 & .000 \\
\hline 3 & $\begin{array}{c}.526 \\
\left(14.05^{*}\right)\end{array}$ & & & $\begin{array}{c}-2.56 \\
\left(-7.81^{*}\right)\end{array}$ & & & .449 & .441 & 61.02 & .000 \\
\hline 4 & $\begin{array}{c}.337 \\
\left(10.34^{*}\right)\end{array}$ & & & & $\begin{array}{c}-.014 \\
(-2.91 *)\end{array}$ & & .102 & .09 & 8.48 & .005 \\
\hline 5 & $\begin{array}{c}.293 \\
\left(5.308^{*}\right)\end{array}$ & & & & & $\begin{array}{c}-.107 \\
(-.058)\end{array}$ & 000 & 000 & 0.003 & .954 \\
\hline 6 & $\begin{array}{c}.221 \\
(2.54 * *)\end{array}$ & & $\begin{array}{c}.358 \\
(3.81 *)\end{array}$ & $\begin{array}{c}-2.19 \\
(-6.94 *)\end{array}$ & & & .539 & .526 & 43.24 & .000 \\
\hline 7 & $\begin{array}{c}.537 \\
\left(14.5^{* *}\right)\end{array}$ & & & $\begin{array}{c}-2.403 \\
(-7.28 *)\end{array}$ & $\begin{array}{c}-.007 \\
(-1.99 * *)\end{array}$ & & .477 & .463 & 33.71 & .000 \\
\hline 8 & $\begin{array}{c}-.037 \\
(-.293)\end{array}$ & $\begin{array}{c}.05 \\
\left(2.78^{*}\right)\end{array}$ & $\begin{array}{c}.452 \\
\left(4.69^{*}\right)\end{array}$ & $\begin{array}{c}-2.865 \\
\left(-7.40^{*}\right)\end{array}$ & & & .583 & .566 & 34.03 & .000 \\
\hline 9 & $\begin{array}{c}-.019 \\
(-.142)\end{array}$ & $\begin{array}{c}.051 \\
\left(2.78^{*}\right)\end{array}$ & $\begin{array}{c}.432 \\
(3.94 *)\end{array}$ & $\begin{array}{c}-2.861 \\
\left(-7.34^{*}\right)\end{array}$ & $\begin{array}{l}-.001 \\
(-.38)\end{array}$ & & .584 & .561 & 25.26 & .000 \\
\hline 10 & $\begin{array}{c}.243 \\
(2.39 *)\end{array}$ & & $\begin{array}{c}.281 \\
\left(2.45^{* *}\right)\end{array}$ & $\begin{array}{c}-2.48 \\
\left(-6.95^{*}\right)\end{array}$ & $\begin{array}{c}.000 \\
(-.085)\end{array}$ & $\begin{array}{c}2.55 \\
(1.75)\end{array}$ &, 558 & .533 & 22.71 & .000 \\
\hline 11 & $\begin{array}{c}.003 \\
(.025)\end{array}$ & $\begin{array}{c}.048 \\
\left(2.65^{*}\right)\end{array}$ & $\begin{array}{c}.371 \\
(3.217 *)\end{array}$ & $\begin{array}{c}-3.077 \\
(-7.500 *)\end{array}$ & $\begin{array}{l}-.001 \\
(-.26)\end{array}$ & $\begin{array}{l}2.193 \\
(1.55)\end{array}$ & .598 & .569 & 21.08 & .000 \\
\hline
\end{tabular}

Table 6 describes about regression of independent variables on long term debt ratio. Profitability has been found to be an important factor affecting total debt as beta coefficients are consistently negative and statistically significant at 1 percent level of significance in all the equitation. It indicates that higher the profitability ratio, lower would be the long term debt.Tangibility has been found to be an important factor affecting total debt as beta coefficients are consistently positive and statistically significant at 1 percent and 5 percent level of significance in all the equitation. It indicates that higher the tangibility ratio, higher would be the long term debt. The regression coefficients for size and non debt tax shield are neither consistent nor statistically insignificant in all regression equations indicating that size and non debt tax shield are not the major factor of determinant of long term debt.

\section{Conclusion and Implications}

The conclusion of this study is that the asset tangibility, profitability, liquidity and non debt tax shield are the major determinants of corporate capital structure in Nepalese hydropower companies. These factors affect differently to different measurement of leverage. Liquidity has been found to be an important factor affecting total debt as beta coefficients are consistently negative and statistically significant. Tangibility has been found to be an important factor affecting total debt as beta coefficients are consistently positive and statistically significant. It indicates that higher the tangibility ratio, higher would be the long term debt and total debt. Non debt tax shield are positively influence the total debt where as profitability and liquidity are negatively influence on the total debt decision of the Nepalese hydropower companies. Size are neither consistent nor statistically insignificant in all regression equations indicating that size variable is not the major factor of determinant of total debt as well as long term debt. Profitability has been found to be an 
important factor affecting total debt as well as long term debt as beta coefficients are consistently negative and statistically significant. It indicates that higher the profitability ratio, lower would be the total debt.

This study can be helpful to investors, shareholders, security analysts, academicians, and students of finance to know the main factors that affect the capital structure of Nepalese Hydropower companies. It would equally valuable to extend the study in other firms like financial and non-financial, listed and none listed firms of the country by adding other variables like inflation, GDP growth, interest rate, corporate governance, legal framework, and impact of the country's financial system could be added.

\section{References}

Adhikari, P. R. (2010). Capital structure and cost of capital: The Nepalese evidence (Unpublished M. Phil. thesis). Tribhuvan University, Kathmandu, Nepal.

Baker, M., \& Wurgler, J. (2002). Market timing and capital structure. Journal of Finance, 57(1), 271-372.

Baral, K. J. (1996). Capital structure and cost of capital in public sector enterprises in Nepal (Unpublished doctoral dissertation). Delhi University, New Delhi, India.

Baral, K. J. (2004). Determinants of capital structure: A case study of listed companies of Nepal. The Journal of Nepalese Business Studies, 1(1), 1-13.

Bhattarai, Y. R. (2008). Determinants of capital structure: The Nepalese evidence (Unpublished M. Phil. thesis). Faculty of Management, Tribhuvan University, Nepal.

Fauzi, F., Basyith, A. \& Idris, M. (2013). The determinants of capital structure: An empirical study of New Zealand listed firms. Asian Journal of Finance \& Accounting, 5(2), 1-21.

Ghazouani, T. (2013). The capital structure through the trade-off theory: Evidence from Tunisian firm. International Journal of Economics and Financial Issues, 3(3), 625-636.

Gujarati, D. (1995). Basic econometrics. New York: McGraw Hill Irwin.

Guney, Y., \& Hussain, H. I. (2012). Capitals structure and market timing in the UK: Deviation from target leverage and security issue choice. Journal of Finance and Banking, 21, 1-43.

Harris, M., \& Raviv, A. (1991). The theory of capital structure. Journal of Finance, 46(2), 297-355.

Hovakimian, A. (2006). Are observed capital structure determined by equity market timing?. The Journal of Financial and Quantitative Analysis, 41(1), 221-243.

Hovakimian, A., Hovakimian, G., \& Tehranian, H., (2004). Determinants of target capital structure: The case of dual debt and equity issues. Journal of Financial Economics, 71(2004), 517-540.

K. C., B. K. (1994). The financing of corporate growth: A case study of Nepal (Unpublished doctoral dissertation). Delhi University, New Delhi, India.

Li, A.Y., \& Tam, H. K. (2012). Transaction costs and impact of market timing on financing decisions: International evidence. Journal of Corporate Finance, 23, 1-46.

Liu, L. (2009). Historical market-to-book in a partial adjustment model of leverage. Journal of Corporate Finance, 15(5), 600-612.

Miller, M. H. (1977). Debt and taxes. Journal of Finance, 32(2), 261-275.

Modigliani, F., \& Miller, M. (1963). Corporate income taxes and the cost of capital: A correction. American Economic Review, 53(3), 443-453.

Modigliani, F., \& Miller, M. H. (1958). The costs of capital, corporation finance and theory of investment. American Economic Review, 48(3), 261-297.

Mokhova, N., \& Zinecker, M. (2013). The determinants of capital structure: The evidence from the European Union. Acta Universities Agriculture et. Silviculture Mendelianae Brunesis, 61(7), 2533-2546.

Myers, S. C. (1977). Determinants of corporate borrowing. Journal of Financial Economics, 5(2), 147-175.

Myers, S. C. (1984). The capital structure puzzle. Journal of Finance, 39(3), 575-592.

Myers, S. C. (2001). Capital structure. The Journal of Economic Perspectives, 15(2), 81-102.

Myers, S., \& Majluf, N. (1984). Corporate financing and investment decisions when firms have information that investors do not have. Journal of Financial Economics, 13(2), 187-221. 
Pant, P. R,. \& Wolf, H. K. (1999). Social science research and thesis writing. Kathmandu: Buddha Academic Enterprises.

Pokharel, P. R. (2011). Determinants of capital structure in Nepalese pharmaceuticals companies (Unpublished M. Phil. thesis). Faculty of Management, Tribhuvan University, Nepal.

Poudel, R. B. (1994). Industrial finance in Nepal (Unpublished doctoral dissertation), Faculty of Management, Tribhuvan University, Nepal.

Pradhan, R. S. (1986). Management of Working Capital. New Delhi: National Book Organization.

Pradhan, R. S. (2003). Research in Nepalese Finance. Kathmandu: Buddha Academic Publishers and Distributors.

Sherpa, L. G. (2007). Corporate capital structure and its determinants: A case of Nepal (Unpublished M. Phil. thesis). Faculty of Management, Tribhuvan University, Nepal.

Shrestha, M. K. (1985). Analysis of capital structure in selected public enterprises. Nepalese Journal of Public Administration, 16(2), 41-57.

Shrestha, R. D. (1993). Focus on Capital Structure. Prabaha, 10, 34-38.

Shyam, S. L,. \& Myers, S. (1999). Testing Static trade-off against pecking order models of capital structure. Journal of Financial Economics, 51(1999), 219-244.

Van Horne, J. C. (2002). Financial management and policy. New Delhi: Pearson Education. 